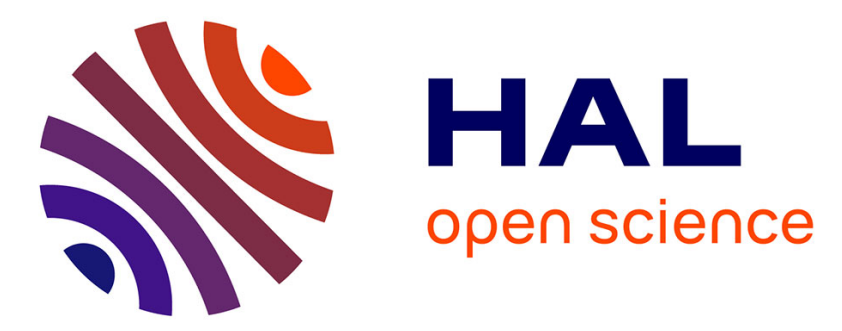

\title{
Cree language use in contemporary children's literature
} Julia Schillo, Mark Turin

\section{To cite this version:}

Julia Schillo, Mark Turin. Cree language use in contemporary children's literature. Book 2.0, 2019, 9 (1-2), pp.163-170. 10.1386/btwo_00015_1. halshs-03083469

\section{HAL Id: halshs-03083469 \\ https://shs.hal.science/halshs-03083469}

Submitted on 22 Jan 2021

HAL is a multi-disciplinary open access archive for the deposit and dissemination of scientific research documents, whether they are published or not. The documents may come from teaching and research institutions in France or abroad, or from public or private research centers.
L'archive ouverte pluridisciplinaire $\mathbf{H A L}$, est destinée au dépôt et à la diffusion de documents scientifiques de niveau recherche, publiés ou non, émanant des établissements d'enseignement et de recherche français ou étrangers, des laboratoires publics ou privés.

\section{(이)(\$)}

Distributed under a Creative Commons Attribution - NonCommercial - NoDerivatives| 4.0 
Book 2.0

Volume 9 Numbers 1 \& 2

(C) 2019 Intellect Ltd Article. English language. doi: 10.1386/btwo_00015_1

\section{Cree language use in contemporary children's literature}

\begin{abstract}
An increasing number of children's books are being written, illustrated and published in Indigenous languages, responding to the urgent need for children to be exposed to their ancestral languages to further the goals of language revitalization across all ages and restore intergenerational language transmission. Such publications range in style from instructional language-learning books that feature a picture alongside associated text - helping children to learn words in a manner similar to using flashcards - to fully developed storybooks written entirely in an Indigenous language or in a bilingual format, with an Indigenous language and an official, national or colonial language sharing the same page. This article focuses on three recent books that have adopted the final approach outlined above - using English as the primary medium with Cree woven into the text throughout the book: Nimoshom and His Bus (Thomas 2017); Stolen Words (Florence 2017); and Awâsis and the World-Famous Bannock (Hunt 2019).
\end{abstract}

While books written fully in an Indigenous language are an invaluable tool for both fluent speakers and learners approaching fluency, they are not accessible to everyone who is engaged, or wishes to become engaged, in revitalization. In many cases, as a direct consequence of colonization and the ongoing

\section{KEYWORDS}

Cree

children's literature language learning revitalization intergenerational 
1. Cree is not a single language, but a number of languages in the Algonquian language family that form a dialect continuum, which is to say that while neighbouring dialects are mutually intelligible, other varieties are not. The Cree languages cover an expansive geographical region, from Labrador to British Columbia, and north into the Northwest Territories. When all Cree dialects classified under the umbrella term 'Cree' are counted together, they comprise the largest number of speakers of an Indigenous language in Canada, with 96,575 as of 2016 (Canadian Heritage n.d.; Government of Northwest Territories n.d.; Statistics Canada 2017). structural violence to which Indigenous communities have been and are still being subjected (Pine and Turin 2017), parents may not consider themselves to be sufficiently fluent in their language or confident in their own abilities to be able to teach their children, despite wanting their children to grow up with exposure to their ancestral language. In these instances, family-friendly learning resources for parents and children alike are needed (Hermes and King 2013; Hinton 2011). Books primarily written in a settler language, such as English, with words and phrases in an Indigenous language integrated into the story, can also be of great assistance to families working to regain spoken and written language ability. Such an approach enables parents with elementary language skills to introduce children to their languages, while staying within their lexical and grammatical range, and to practice their own language skills at the same time. In other cases, such as those where no family member speaks or reads the language, the deliberate and careful introduction of words and phrases in the Indigenous language supports entire families - parents and children alike - in the challenging task of relearning and reclaiming their ancestral language.

\section{THREE BOOKS}

Three recent books that have adopted the final approach outlined above using English as the primary medium with $\mathrm{Cree}^{1}$ woven into the text throughout the book: Nimoshom and His Bus (Thomas 2017); Stolen Words (Florence 2017); and Awâsis and the World-Famous Bannock (Hunt 2019). Despite some similarities of approach in terms of incorporating Cree into the English text, each author makes use of the Cree language for a different purpose in the narrative, and for the most part, different words are introduced in each. These three books offer distinct and compelling approaches to using an Indigenous language in contemporary children's literature and deserve wide recognition for both the content and chosen format. Each book offers an example of an important and exciting category of children's literature used for languagelearning purposes and illustrates the power and impact that children's literature can have.

Nimoshom and His Bus (2017) was written by Penny M. Thomas and illustrated by Karen Hibbard. Thomas is an Ojibwe-Cree writer who has written two books to date, the other being Powwow Counting in Cree, published in 2013, which won the McNally Robinson Book for Young People Award. Both books are written in English but incorporate Cree words. Nimoshom and His Bus is a model instructional book for language learning. The story follows a school bus driver, whom the narrator refers to as nimoshom, meaning 'my grandfather' in Cree. Nimoshom often uses Cree words and phrases while chatting with the students onboard his bus. The context of the word/phrase is first introduced in English, followed by nimoshom saying the word in Cree. Another sentence then follows with the English translation. For example, the fourth spread reads: 'When kids played around on the bus, nimoshom would say: "Api!"Api means sit down'.

Hibbard illustrates the story in watercolour, and the energy of the narrative translates into each colourful spread. Whether a result of the moving bus, a running dog or children playing, the illustrations always appear to be in motion. Smiles grace the faces of nimoshom and all of the young students aboard his bus, and a true sense of the camaraderie on the school bus can be felt in each of the lively images. 
In an interview with Matthew Winner on 'The Children's Book Podcast' (2017: 00:04:48-00:05:51), Thomas explained that she wanted the book to be about the language, and opted to use the publication to highlight some commonly used Cree words such as tansi for 'hello', ehe and mots for 'yes' and 'no', respectively and kinapi for'hurry up'. Many of the words that she included were words that her children already knew. At the same time, Nimoshom and His Bus pays homage to her grandfather, who was himself a school bus driver, shedding light on her decision to call the bus driver nimoshom. In addition to the Cree words and their English definitions presented throughout the text, a helpful glossary of terms together with a pronunciation guide is included at the back of the book. The pronunciation guide is not in the International Phonetic Alphabet or the North American Phonetic Alphabet, but instead uses equivalent spellings that English speakers would easily understand, helping readers without any specific linguistic knowledge to navigate the language. For example, the glossary entry for the word ekosani reads:

\section{Ekosani $\bullet$ eh-ko-SAH-nee $\bullet$ thank you}

Similarly formatted glossaries are found in the other two books discussed later in the article.

Nimoshom and His Bus offers an empowering approach to activating language for families who already use elements of Cree at home, but may not think of themselves as fluent. It also serves as a strong introduction to the language for anyone looking to learn more or teach their children.

Stolen Words (2017) was written by Melanie Florence and illustrated by Gabrielle Grimard. Florence is a Toronto-based writer of Cree and Scottish heritage whose previous children's book Missing Nimâmâ (2015) won the 2016 TD Canadian Children's Literature Award. Like Thomas, Florence draws inspiration from her grandfather's experience with the Cree language (2017), but in her case, the focus is on the impact of residential schools on language transmission. In both Canada and the United States, Indian residential schools sought to erase Indigenous languages and cultures in order to assimilate Indigenous children into mainstream Euro-North American society, and many students were physically, sexually and emotionally abused while in residence. As a direct consequence of the residential school experience, many who attended and survived stopped using their native languages (Pine and Turin 2017). Florence does not shy away from approaching difficult and painful topics in her publications: Missing Nimâmâ addresses the crisis of the 4000 Missing and Murdered Indigenous Women and Girls in Canada. The murder rate of Indigenous women and girls is twelve times higher than any other demographic group in Canada, and the Canadian National Inquiry into Missing and Murdered Indigenous Women and Girls recently characterized this crisis as a'Canadian genocide' (Tasker 2019).

Stolen Words opens with a young girl walking home with her grandfather, carrying a dream catcher that she made at school. When she asks him how to say 'grandfather' in Cree, he replies that he does not remember because his words were stolen from him. He then describes his experiences at residential school. The Cree language is depicted as a large black bird that flies from the children's mouths into a cage held by a priest in a spread depicting a flashback to residential school. Grimard's pencil and watercolour illustrations feature many close-ups of the faces of the young girl and her grandfather, showing the emotion of recounting these memories. 
The next day, the girl asks her teacher to help her find an introductory Cree book at school. When her grandfather picks her up at the conclusion of the school day, she greets him in Cree. She then gives him the book so that he can remember his language. As the grandfather opens the book and reads, the ink on the pages turns into an open cage, with black birds flying free and cursive Cree words, such as têniki ('language'), trailing from their legs.

While Stolen Words presents a more restricted set of Cree words than Nimoshom and His Bus, the choice of words and their impact is particularly poignant. Cree words are not introduced until the very end of the story, and the granddaughter is the first to speak them. The grandfather then reads the introductory Cree book and begins to remember and relearn his own language. Stolen Words concludes with the grandfather and granddaughter agreeing to read the book and learn together.

By addressing a painful and difficult past, and its impact on survivors in the present, Stolen Words offers an inspiring example of language relearning across and between the generations, and is a particularly timely publication as Canada grapples with its historic and ongoing complicity in the marginalization and dispossession of Indigenous communities.

Finally, we focus on Awâsis and the World-Famous Bannock (2019) by Dallas Hunt, illustrated by Amanda Strong. Hunt is a member of Wapisewsipi, the Swan River First Nation in Alberta, and is a professor at the University of British Columbia in Vancouver. This is his debut children's book and it demonstrates his commitment to language revitalization (Anon. n.d.a). Awâsis and the World-Famous Bannock tells the story of a young girl named Awâsis ('child') walking through the forest and carrying her grandmother's bannock (a form of flat bread) to give to other relatives. She accidentally drops the bannock into a stream and receives help from various animals, who provide her with the ingredients to make bannock. Returning home to her grandmother, Awâsis gives her grandmother the ingredients and together they make a fresh batch of bannock to share with her new animal friends.

Strong's whimsical illustrations beautifully capture the excitement of a child navigating the forest. Awâsis' stylized face reveals the emotional highs and lows of her journey, from the despair at having lost her grandmother's bannock to the joy of making new friends. A large bear follows her from a distance throughout the story, only to provide her with the last missing ingredient (tohtôsâpoy'milk') in the final spread.

The Cree language is woven through the entire fabric of this story, with each character's name provided in Cree (grandmother, owl, rabbit, etc.), as well as greetings and all of the ingredients that are used to make bannock. The use of the Cree language reflects the elements of the story that Hunt found most culturally significant, such as familial relations, animals and bannock ingredients. Hunt also opted to have Ôhô ('owl') use they/them pronouns. In an interview with Highwater Press, Hunt explains this decision as an effort'to normalize gender variance and gender diversity within our languages and communities' (Anon. 2019). Although the pronouns provided are in English, the use of they/ them indicates that equivalent gender non-binary pronouns could be used in Cree. Hunt points out the importance of showing that Cree is able to express a full range of 'relations', to underscore that Cree is not and should not become a static language, and to demonstrate that Cree can represent diverse gender identities (Anon. 2019). Throughout this engaging and enjoyable book, Hunt emphasizes the importance of the relationships between Awâsis and those she encounters, and uses Cree to facilitate their interactions. 
A number of themes and commonalities emerge from all three publications. First, the intimate connection between the Cree language and Cree culture is underscored in each of the three books. In each case, Cree is crucial to the cultural content of the story. In Nimoshom and His Bus, for example, the word used when departing, ekosi, is not translated as 'goodbye', although it is used in a similar way, but is rather translated as, 'okay', 'that's it' or 'amen'. This illustrates a concept in the Cree language that does not have a direct translation in English, and highlights the importance of knowledge of Cree for understanding nimoshom's feelings and expressions. The power of even small uses of Indigenous languages throughout children's literature has been noted to play a'pivotal role' in the immersive quality of the books, including in their cultural content (Korteweg et al. 2010). Similarly, the use of Cree in Awâsis and the World Famous Bannock directly reflects Cree concepts of kinship. In an interview, author Dallas Hunt explains:

It is important to me that Awâsis and the other characters not only speak Cree, but that they have a relationship premised on sharing and respect. So often our relation to 'the natural world' and our other-thanhuman kin can be based on extraction or extractive logics, so I wanted to put forth other ideas in the book, ones that might reflect or be more in line with Cree teachings or Cree ways of being in the world.

(Anon. 2019)

These relations are given life and meaning through the use of Cree. Awâsis exclusively refers to her grandmother as kôhkum, meaning' 'grandmother', who in turn refers to Awâsis as nôsisim, meaning 'grandchild'. Similarly, all of the animals that Awâsis meets are also addressed and referred to by their Cree names, showing the bond that they have with Awâsis. This contributes to an emerging trend in Indigenous children's literature that discusses the relationships between people, land, and the various creatures that live there, which can be described using the expression 'all our relations' (Korteweg et al. 2010). The powerful and contextual use of Cree to refer to and discuss relationships is also demonstrated in the other books, such as the bus driver in Nimoshom and His Bus who is addressed as nimoshom. In Stolen Words, the story opens with the girl asking her grandfather how to say 'grandfather' in Cree. At the end, when grandfather is reading and remembering his language, one of the six words that he remembers is nôsisim, meaning 'grandchild', same word used by Awâsis' grandmother. Awâsis and the World-Famous Bannock also underscores the cultural significance of bannock by using Cree words for each of the ingredients. This follows an exciting trend in children's literature, and literature more generally, of referring to food and foodstuffs in the Indigenous language of the character (see also A Walk on the Tundra 2011 by Rebecca Hainnu and Anna Ziegler, a children's book about a grandmother who takes her granddaughter to collect plants that she talks about in Inuktitut).

Another central theme that emerges from all three books is the importance of intergenerational relationships and the centrality of language in nurturing such relations. In Nimoshom and His Bus, nimoshom interacts with the children on the bus and transmits his language to them. Awâsis speaks Cree with her grandmother throughout the book, and the granddaughter in Stolen Words is the one who helps bring language back for her grandfather. In different ways, each of these books underscores the importance of the entire family unit being engaged in the process of language revitalization, with each 
generation playing a crucial role in stabilizing the language. These works also speak to a phenomenon observed in many contemporary language revitalization movements, in which the principal speakers of a language are the oldest and youngest generations. All three publications offer compelling insights into the goals of language reclamation and revitalization: namely, the stabilization of Indigenous language use within a community through children speaking it.

As outlined by First Peoples' Cultural Council in one of their helpful 2018 Fact Sheets on First Nations languages and revitalization, taking steps such as using one's language in the home and enrolling children in immersion programmes are important to healing the language continuum that has been ruptured by colonization (2018). Another theme, most immediately apparent in Stolen Words, is the complex relationship that each generation has with schooling. While the grandfather attended residential school and lost access to his Cree language as a direct consequence, his granddaughter attends a school that recognizes and even celebrates Indigenous culture (as shown by the dreamcatcher that she made), with her teacher helping to locate a Cree language book to return the language to her family. These examples emphasize the complicated role that schools play in bringing languages back to communities. While schools had a strong hand in the attempt to extinguish Indigenous languages in North America, educational institutions are now at the forefront of revitalization work, of both language and of culture. As Senator and Justice Murray Sinclair, Chief Commissioner of the Truth and Reconciliation Commission, so powerfully stated, 'it is precisely because education was the primary tool of oppression of Aboriginal people, and miseducation of all Canadians, that we have concluded that education holds the key to reconciliation' (Anon. 2015).

Powerful examples are the language immersion schools increasingly seen across North America, drawing inspiration from Hawaii and Aotearoa New Zealand, in which all classes are taught in the Indigenous language of the area, and curriculum is structured to emerge from the cultural context of the local host Nation (Hinton 2011). The importance of intergenerational communication and transmission - of culture, language and knowledge - is central to each of these significant publications, a transmission that will become activated through the families that read them.

Each of these books incorporates and engages with Cree, and each contributes to the growing momentum in the renewed use of Indigenous languages. While each publication includes and activates a distinct range of Cree words, there is also overlap, particularly around kinship terminology. These imaginative Indigenous-authored publications achieve distinct goals: Nimoshom and His Bus teaches the reader Cree words, Stolen Words engages with a history of abuse and trauma while also outlining a path for healing, while Awâsis and the World-Famous Bannock helps to impart a Cree worldview about the centrality of relationships. These creative and influential books deserve wide circulation in schools, public libraries and private homes in North America and beyond.

\section{REFERENCES}

Anon. (2015),'Education for reconciliation', Teacher Magazine, 28:1, September/ October, https://bctf.ca/publications/TeacherArticle.aspx?id=38000. Accessed 11 June 2019.

(2019), 'Language revitalization \& gender diversity: Dallas Hunt's interview about "Awâsis and the world-famous bannock,"', Portage \& Main 
Press, 15 January, http://www.portageandmainpress.com/blog/2019/01/15/ dallas-hunt-interview-awasis-and-the-world-famous-bannock/. Accessed 4 June 2019.

—_ (n.d.a), 'Dallas Hunt', Portage \& Main Press, https://www.portageandmainpress.com/authors/dallas-hunt/. Accessed 5 June 2019.

—_ (n.d.b), 'My story', Melanie Florence: Author, https://www.melanieflorence.com/my-story. Accessed 5 June 2019.

— (n.d.c), 'Penny M. Thomas', Portage \& Main Press, https://www.portageandmainpress.com/authors/penny-m-thomas/. Accessed 5 June 2019.

Canadian Heritage (n.d.), 'Indigenous language in Canada', Canadian Heritage, https://www.itk.ca/wp-content/uploads/2017/06/TableauFiP_ EN.pdf. Accessed 4 June 2019.

The Children's Book Podcast (2017), 'Penny Thomas', interview by Matthew Winner, 15 December, https://lgbpodcast.libsyn.com/penny-thomas. Accessed 2 June 2019.

First Peoples' Cultural Council (2018), 'Fact sheets 5 \& 9', First Peoples' Cultural Council, 21 March, http://www.fpcc.ca/about-us/news-room/ news10161701.aspx. Accessed 4 June 2019.

Florence, Melanie (2015), Missing Nimâmâ (illust. F. Thisdale), Keswick: Clockwise Press.

_ (2017), Stolen Words (illust. G. Grimard), Toronto: Second Story Press.

Government of Northwest Territories (n.d.), 'Official languages overview', Government of Northwest Territories, https://www.ece.gov.nt.ca/en/services/secretariat-des-langues-autochtones/official-languages-overview. Accessed 4 June 2019.

Hainnu, Rebecca and Ziegler, Anna (2011), A Walk on the Tundra (illust. Q. Leng), Iqaluit: Inhabit Media.

Hermes, Mary and King, Kendall A. (2013), 'Ojibwe language revitalization, multimedia technology, and family language learning', Language Learning \& Technology, 17:1, pp. 125-44.

Hinton, Leanne (2011), 'Language revitalization and language pedagogy: New teaching and learning strategies', Language and Education, 25:4, pp. 307-18.

Hunt, Dallas (2019), Awâsis and the World-Famous Bannock (illust. A. Strong), Winnipeg: Highwater Press.

Korteweg, Lisa, Gonzalez, Ismel and Guillet, Jojo (2010), 'The stories are the people and the land: Three educators respond to environmental teachings in Indigenous children's literature', Environmental Education Research, 16:3\&4, pp. 331-50.

Pine, Aidan and Turin, Mark (2017), Language Revitalization, Oxford: Oxford University Press and Oxford Research Encyclopedia, https://oxfordre. com/linguistics/view/10.1093/acrefore/9780199384655.001.0001/acrefore9780199384655-e-8\#. Accessed 3 June 2019.

Statistics Canada (2017), 'The Aboriginal languages of First Nations people, Métis and Inuit', Statistics Canada, 25 October, https://www12.statcan. gc.ca/census-recensement/2016/as-sa/98-200-x/2016022/98-200x2016022-eng.cfm. Accessed 4 June 2019.

Tasker, John Paul (2019), 'Inquiry into missing and murdered Indigenous women issues final report with sweeping calls for change', Canadian Broadcasting Corporation, 3 June, https://www.cbc.ca/news/politics/ mmiwg-inquiry-deliver-final-report-justice-reforms-1.5158223. Accessed 3 June 2019. 
Thomas, Penny M. (2013), Powwow counting in Cree (illust. M. Josie), Winnipeg: Portage \& Main Press.

- (2017), Nimoshom and His Bus (illust. K. Hibbard), Winnipeg: Highwater Press.

Winnipeg International Writers Festival (n.d), 'Penny M. Thomas', Winnipeg International Writers Festival, https://thinairwinnipeg.ca/writers/pennym-thomas/. Accessed 5 June 2019.

\section{CONTRIBUTOR DETAILS}

Julia Schillo is an undergraduate research assistant at the University of British Columbia. She is a Linguistics major and First Nations and Endangered Languages minor with a specific interest in language revitalization in the Pacific Northwest region of North America. Additionally, she has previously studied Graphic Design, which informs much of her current work and has led to research in Nepal, Canada and the United States.

E-mail: schilloji@gmail.com

ㅂ. https://orcid.org/0000-0003-0560-2564

Mark Turin is an anthropologist, linguist and occasional radio presenter, and an associate professor of anthropology at the University of British Columbia, Vancouver, Canada. He has worked in the Himalayan region (Nepal, Bhutan, northern India and Tibet) since the early 1990s and in Western Canada since 2014. He is the author or co-author of four books, three travel guides, the editor of nine volumes and he edits a series on oral literature. He tweets @markturin.

E-mail: mark.turin@ubc.ca

‥ http://orcid.org/0000-0002-2262-0986

Julia Schillo and Mark Turin have asserted their right under the Copyright, Designs and Patents Act, 1988, to be identified as the authors of this work in the format that was submitted to Intellect Ltd. 
Copyright of Book 2.0 is the property of Intellect Ltd. and its content may not be copied or emailed to multiple sites or posted to a listserv without the copyright holder's express written permission. However, users may print, download, or email articles for individual use. 